ISSN: 2224-0616

Int. J . Agril. Res. Innov. \& Tech. 4 (1): 36-39, J une, 2014

Available online at http:/ / www.ijarit.webs.com

\title{
WOMEN'S PARTICIPATION IN RICE MILLS IN SHERPUR SADAR UPAZILA OF BANGLADESH
}

\author{
Naima Sultana ${ }^{1}$ and M.S.I. Afrad ${ }^{2 *}$ \\ Received 2 January 2014, Revised 29 May 2014, Accepted 28 June 2014, Published online 30 June 2014
}

\begin{abstract}
The main purpose of this study was to determine women's participation in rice mills of Sherpur sadar upazila of Bangladesh. Ninety respondents were selected using cluster random sampling method. The researchers personally collected data from August to September 2012. Aimed at explaining the assessment of the present status of women worker of rice mills and explored the relationship between their selected characteristics and extent of participation. Majority of the respondents had long experience in working in the rice mill and almost everybody had participation around the year. Women were mostly involved in drying and on an average spent time for helping in husking machine operating (3.02 hours) followed by final drying of paddy ( 2.05 hours), drying the paddy before boiling ( 1.25 hours), piling the paddy (1.12 hours), cleaning the threshing floor (1.05 hours), packing the rice (1.02 hours) per day. They worked about 8-10 hours per day. Results show that the women worker's performance decreased with the increase of their age.
\end{abstract}

Keywords: Rice Mills, Women's Participation

${ }^{1}$ Former MS student, Dept. of Agril. Ext. and Rural Development, BSMRAU, Gazipur, Bangladesh

${ }^{2}$ Professor, Dept. of Agril. Ext. and Rural Development, BSMRAU, Gazipur, Bangladesh

*Corresponding author's email: afrad69@gmail.com (M.S.I. Afrad)

\section{Introduction}

Rice is the most important staple food in Bangladesh. More than 70 per cent of the total calorie intake comes from this food item. The per capita consumption (about $400 \mathrm{~g} /$ day) of rice in Bangladesh is one of the highest in the world (IFRI, 2013). Rice cultivation in Bangladesh covers more than 70 per cent of the total cropped area (Begum, 1997). Three types of rice, namely aus (summer), aman (winter) and boro (spring) are grown in Bangladesh. When the paddy is harvested from fields, it needs to be processed for consumption. Parboiling, drying and milling are the different stages of getting rice from paddy. These are done both at home (small scale) and at the rice mills (large scale). Processing at home, the non-commercial sector of milling is perhaps the oldest and almost obsolete form of rice processing method in Bangladesh. In this method, paddy is processed in dheki ${ }^{1}$ after it is parboiled and dried. Paddy processing and milling in Bangladesh is mostly performed at the rice mills. These mills are called commercial milling center. There are three kinds of commercial mills available in Bangladesh. They are husky, major and automatic. Increasing trend in mechanical process unit in the market has gradually replaced the traditional method of rice processing. These commercial- processing units have been playing a significant role in the rice marketing system (Zaman et al., 2003).
In Bangladesh, there are approximately 40,000 rice mills. Rice mills are very much dependent on human labor, and almost 5 millions of unorganized workers are working in different rice mills and more than 60 per cent of them are female worker (Anonymous, 2003). Women workers are responsible for drying and husking paddy and packing the husked rice into sacks. Male workers are responsible for doing the less laborious works (Siddika, 2012).

The above-mentioned discussion implies the importance of women's participation in Bangladeshi rice milling sector. Therefore, keeping the importance in mind the present study was undertaken to explore the extent of participation by the respondents in the rice mills in the selected area. The relationship between the selected characteristics of the respondents and their participation in the rice mills will be also identified.

\section{Methodology}

Sherpur sadar upazila was purposively selected for the study. Accordingly, a list of rice mills was collected from the rice mill owner association of Sherpur. List shows that there are 391 rice mills in the study area. From the list, four rice mills namely, M/S Bangla Rice Mill, M/S Ruman Suman Rice Mill, M/S Jisan Rice Mill and M/S 
Aditi Rice Mill were selected following cluster sampling technique. Then the researcher collected list of women workers from the managers or the owners of the selected rice mills. In each mill, 20 to 30 women have been working daily or permanent basis. Thus, all women workers of these four rice mills were the sample of this study, which was 90 in number (from M/S Bangla Rice Mill 27, from M/S Ruman Suman Rice Mill 22, from M/S Jisan Rice Mill 21 and from M/S Aditi Rice Mill 20 respondents). Data were collected through face-to-face interview method using pre-design and pre-tested interview schedules.

Selected characteristics of the respondents such as age, education, family size, properties, earning member in the family, marital status, family type, physical fitness, working experience, relation with superiors or mill-owner, relation with colleague/ fellow worker, contribution to the family were considered as the independent variables of the study and computing appropriate scores. The characteristics were measured either raw scores or through rated scores. Amount of time spent by women rice mill worker was the dependent variable of the study. It was measured by calculating the actual time spent (in hour) in the rice mill by the respondent women. Total time spent by the respondents in different activities of rice mill was identified in hours per day.

\section{Results and Discussion}

\section{Personal characteristics of the respondents}

The results indicate that most of the respondents are middle aged (65\%), illiterate (54\%), married (66\%), medium family size (59\%) and respondent and their husbands are the main earning member in their family (49\%).

Table 1. Distribution of the respondents according to their personal characteristics

\begin{tabular}{|c|c|c|c|c|c|}
\hline Characteristics & Categories & Number & Per cent & Mean & SD \\
\hline \multirow{3}{*}{ Age } & Young (up to 35year) & 1 & 1 & \multirow{3}{*}{48.31} & \multirow{3}{*}{6.14} \\
\hline & Middle (36 to 50year) & 58 & 65 & & \\
\hline & Old ( $>50$ year) & 31 & 34 & & \\
\hline \multirow{3}{*}{ Education } & Illiterate & 49 & 54 & \multirow{3}{*}{1.51} & \multirow{3}{*}{0.06} \\
\hline & Signature ability & 36 & 40 & & \\
\hline & Primary education & 5 & 6 & & \\
\hline \multirow{3}{*}{ Family size } & Small (up to 4members) & 35 & 39 & \multirow{3}{*}{4.96} & \multirow{3}{*}{1.11} \\
\hline & Medium (5-7 members) & 53 & 59 & & \\
\hline & Large (above 7 members) & 2 & 2 & & \\
\hline \multirow{3}{*}{ Properties } & Landless & 26 & 29 & \multirow{3}{*}{1.77} & \multirow{3}{*}{0.55} \\
\hline & Only house & 58 & 65 & & \\
\hline & House with a piece of land & 6 & 6 & & \\
\hline \multirow{3}{*}{ Earning member } & Only respondents & 28 & 31 & \multirow{3}{*}{1.88} & \multirow{3}{*}{0.71} \\
\hline & Respondents and her husband & 44 & 49 & & \\
\hline & Respondents and other members of family & 18 & 20 & & \\
\hline \multirow{3}{*}{ Marital status } & Married & 59 & 65 & \multirow{3}{*}{3.47} & \multirow{3}{*}{0.82} \\
\hline & Divorced & 17 & 19 & & \\
\hline & Widow & 14 & 16 & & \\
\hline \multirow{2}{*}{ Family type } & Nuclear family & 81 & 90 & \multirow{2}{*}{1.1} & \multirow{2}{*}{0.30} \\
\hline & J oint family & 9 & 10 & & \\
\hline \multirow{2}{*}{ Physical fitness } & Physically well & 83 & 92 & \multirow[b]{2}{*}{1.07} & \multirow{2}{*}{0.26} \\
\hline & Physically sick & 7 & 8 & & \\
\hline \multirow{3}{*}{ Experience } & Less than12years experience & 34 & 38 & \multirow{3}{*}{13.47} & \multirow{3}{*}{6.43} \\
\hline & 12-18 years experience & 36 & 40 & & \\
\hline & More than 18 years experience & 20 & 22 & & \\
\hline \multirow{4}{*}{$\begin{array}{l}\text { Relation with superiors or } \\
\text { mill owner }\end{array}$} & Amiable & 4 & 5 & & \\
\hline & Cooperative & 76 & 84 & ? & \\
\hline & Respectable & 8 & 9 & 2.08 & 0.46 \\
\hline & Not good & 2 & 2 & & \\
\hline & Amiable & 8 & 9 & & \\
\hline Relation with colleague or & Cooperative & 72 & 80 & & \\
\hline fellow worker & Respectable & 4 & 4 & 2.08 & 0.62 \\
\hline & Not good & 6 & 7 & & \\
\hline & Low( up to 16) & 14 & 15 & & \\
\hline Financial contribution to & Medium (17-18) & 42 & 47 & 18.45 & 2.05 \\
\hline & High(Above 18) & 34 & 38 & & \\
\hline
\end{tabular}


Majority of the respondents (65\%) have only house and of them 92 per cent are physically well. It is also found that 40 per cent of the respondents have long experience (12 to 18 years) in working in the rice mill and almost everybody (93\%) had participation around the year. The mill owners or superiors are cooperative to respondents (84\%) and they have good relationship with their colleagues (80\%). About half of the respondents (47\%) have medium contribution to their family (Table 1).
Gender wise involvement in different activities in rice mill

Most of the activities performed within the rice mill jointly by men and women and, therefore, it is very difficult to find out the exact works performed only by the women. Results presented in the Table 2 indicate that women are mostly involved in drying $(94.44 \%$ in drying before boiling and $96.66 \%$ in final drying).

Table 2. Gender wise involvement in different activities in rice mill

\begin{tabular}{clccc}
\hline Sl. No. & Activities & Female only & Male only & J ointly \\
\hline 1 & Carrying the sack of rice & $0(0)$ & $86(95.55)$ & $4(4.44)$ \\
2 & Drying the rice before boiling & $87(96.66)$ & $0(0)$ & $3(3.33)$ \\
3 & Helping in boiling & $0(0)$ & $88(97.77)$ & $2(2.22)$ \\
4 & Firing the boiler machine & $0(0)$ & $90(100)$ & $0(0)$ \\
5 & Boiler operating & $0(0)$ & $90(100)$ & $0(0)$ \\
6 & Piling the rice & $74(82.22)$ & $7(7.77)$ & $9(10)$ \\
7 & Helping in husking machine operating & $64(71.11)$ & $19(21.11)$ & $7(7.77)$ \\
8 & Cleaning the threshing floor & $83(92.22)$ & $3(3.33)$ & $4(4.44)$ \\
9 & Final drying / drying after boiling & $85(94.44)$ & $0(0)$ & $5(5.56)$ \\
10 & Packing (covering incomplete & $14(15.55)$ & $65(72.23)$ & $11(12.22)$ \\
11 & Others dried & $33(36.60)$ & $15(16.66)$ & $42(46.64)$ \\
& paddy, winnowing etc.) & & & \\
\hline
\end{tabular}

(Figures in parenthesis indicateper cent)

There are less involvement of the women respondent workers in helping in boiling and operating the boiler machine. Rice packing and piling are done jointly (10 and $12.22 \%$, respectively). Carrying the sack (95.55\%), helping in boiling (97.77\%) and boiler operation is almost done by their male counter parts (Table 2).

Extent of participation in the rice mills by women worker

Table 3. Extent of respondent women's participation in the rice mills (hour/ day)

\begin{tabular}{clcc}
\hline \multirow{2}{*}{ Sl. No. } & \multirow{2}{*}{ Activities } & \multicolumn{2}{c}{ Time spent (in hour/ day) } \\
\cline { 3 - 4 } & & Mean & SD \\
\hline 1 & Carrying the sacks of rice & 0.30 & 0.06 \\
2 & Drying the paddy before boiling & 1.25 & 0.38 \\
3 & Helping in boiling & 0.38 & 0.27 \\
4 & Piling the rice & 1.12 & 0.46 \\
5 & Helping in husking machine operating & 3.02 & 0.65 \\
6 & Final drying/ drying after boiling & 2.05 & 0.34 \\
7 & Packing & 1.02 & 0.35 \\
8 & Cleaning the threshing floor & 1.05 & 0.34 \\
9 & Others (covering incomplete dried paddy, winnowing) & 0.25 & 0.05 \\
\hline & Total & 10.44 & \\
\hline
\end{tabular}

Relationship between the extent of relation with their extent of participation in rice participation and the selected characteristics of the respondents

Based on the correlation analysis it is observed that out of seven selected characteristics of the respondents only age have significant negative
Results shown in Table 3 reveal that respondent women worker on an average spend most of their time in rice mills for helping in husking machine operating (3.02 hours) followed by final drying of paddy (2.05 hours), drying the paddy before boiling ( 1.25 hours), piling the paddy (1.12 hours), cleaning the threshing floor (1.05 hours) and packing the rice (1.02 hours) per day. Muhibbullah (2010) reported similar results. increased then their extent of participation in different activities of rice mill would also be increased. 
Table 4. Relationship between extent of participation of the respondents in rice mill and their selected characteristics

\begin{tabular}{lc}
\hline Independent variables & Dependent variable (value of ' $r$ ') \\
\hline 1. Age & $-0.224^{*}$ \\
2. Education & $0.035^{\mathrm{NS}}$ \\
3. Family size & $0.151^{\mathrm{NS}}$ \\
4. Earning member in the family & $0.073^{\mathrm{NS}}$ \\
5. Marital status & $-0.087_{\mathrm{NS}}$ \\
6. Experience & $0.120^{\mathrm{NS}}$ \\
7. Contribution to the family & $0.137 \mathrm{NS}$ \\
\hline
\end{tabular}

(* Significant at 0.05 level of probability, ** Significant at 0.01 level of probability, NS=Not significant)

This might be because with the increase of age, an individual's capacity tends to decrease. Begum (2001) observed similar findings but Tuli (2011) observed different findings in her study.

\section{Conclusion}

From the findings and their logical interpretation, it can be concluded that most of the respondents of the study were middle aged, illiterate, physically sound, married, had a medium family size, respondent and her husband are earning member in their family, possessed only house. Most of the respondents have long experience of working in the rice mill and almost everybody has round the year participation. The mill owner or superiors are cooperative to respondents and good relation with colleagues and medium contribution to the family. Women are mostly involved in drying the paddy and on an average spent time for helping in husking machine operating (3.02 hours) followed by final drying of paddy (2.05 hours), drying the paddy before boiling ( 1.25 hours), piling the paddy (1.12 hours), cleaning the threshing floor (1.05 hours), packing the rice (1.02 hours) per day. Therefore, women in rice mill work about 8-10 hours per day.

\section{References}

Anonymous. 2003. Development project in AGRO-BASED industry. Bangladesh Occupational Safety, Health and Environment Foundation, OSHE. Available at: http:// oshebd.org/grain.html

Begum, F. 2001. Contribution of farmwomen in post-harvest activities of boro rice, pulses and oilseed crops in Narsingdi district of Bangladesh. PhD Thesis. Department of Agricultural Extension and Rural Development. Banghabandhu Sheikh Mujibur Rahman Agricultural University, Gazipur.

Begum, S. 1997. Commodity Report on Food Grain, Research and Planning, Department of Agricultural Marketing, Dhaka.

IFRI. 2013. Zinc Rice. Available at: http:// www.unscn.org/layout/modules/reso urces/files/HarvestPlus_Rice_Strategy_EN. pdf

Muhibbullah, M. 2010. Women's Participation in Homestead Agriculture as a Rural Culture: a micro level study on Barisal district in Bangladesh. Proceedings of International conference on "The Roles of Humanities and Social Sciences in Engineering" held on 1214 November 2010, Penang, Malaysia. 88p.

Siddika, A. 2012. Women in informal sector. The News Today. Newscorp Publications Limited, Dhaka, Bangladesh. July 18, 2012.

Tuli, A.N. 2011. Women's Participation in Household and Agricultural Activities in Selected Area of Gazipur District. MS Thesis, Department of Agricultural Extension and Rural Development, Banghabandhu Sheikh Mujibur Rahman Agricultural University, Gazipur.

Zaman, Z, Tokuzo, M. and Shuji, H. 2003. The role of rice processing industries in Bangladesh: a case study of the Sherpur district. The Review Agril. Econ. 57: 121-133. 